\title{
5
}

\section{Mana, Power and 'Pawa' in the Pacific and Beyond}

\section{Alan Rumsey}

In this chapter I address three interrelated topics pertaining to mana and how it might be understood in relation to 'power' as a socialanalytical construct, and to pawa as a vernacular term used by some Pacific peoples.

First, I briefly review the history of anthropological and comparativelinguistic understandings of mana, from Robert Codrington's boldly speculative account (1891), to Raymond Firth's (1940) much more cautious one, to Roger Keesing's (1984) argument concerning what he takes to be western misconstruals of traditional concepts of mana held by Pacific peoples speaking Oceanic Austronesian languages. I offer some caveats about that argument and update it by reviewing some more recent work by other scholars who have tried to link those words and concepts to others that are attested in Austronesian languages across a wider region than Oceania, and even to Papuan languages extending into the interior of Papua New Guinea (PNG).

Next, turning to my field experience in PNG among speakers of a Papuan language who do not have a word like mana that is used in anything very close to the senses that that word has in Oceanic languages, I discuss the word that they use that comes closest to those senses, namely pawa, a word that has come into the Ku Waru language 
through borrowing from Tok Pisin, but is nowadays very frequently used by people when speaking Ku Waru as the main noun for 'power', in close relation to an inherited Ku Waru word (todul) meaning 'strong'.

Finally, drawing on my discussion of mana and pawa in the first two sections of the chapter, I consider some methodological and theoretical issues involved in the kind of comparative study that is pursued in this volume. I compare its overall approach with that which is taken in two other comparative exercises, the Keywords volumes edited by Raymond Williams (1976) and Tony Bennett, Lawrence Grossberg and Meaghan Morris (2005), and The Gender of the Gift by Marilyn Strathern (1988). I show that the approach taken here is closer to the former than the latter, and argue that that is the more useful approach for understanding the play of mana within the relatively unbounded social field in which it circulates.

\section{Anthropological and comparative-linguistic understandings of mana}

Concepts and practices relating to mana first became widely known to westerners through the writings of the Anglican missionaryanthropologist Robert Codrington in the 1880s and 1890s. Based on his missionary work in the New Hebrides and Solomons, and his knowledge of other peoples and languages including Polynesian ones, Codrington concluded that the word mana was 'common ... to the whole Pacific' (Codrington 1891: 138) and that it referred to a kind of universal, invisible spiritual 'power or influence' which 'attaches itself to persons, and to things' (118-19). Codrington's ethnographic writings on the subject were seized upon by armchair ethnological theorists (Marett, Durkheim, Hubert, Mauss; see Introduction to this volume) who not only accepted his claims about the meaning of this word across the Pacific, but - true to the evolutionist paradigm of the day - took his account of mana as evidence for the nature of so-called 'primitive mentality' in general, and as the category that most nearly expressed the essence of rudimentary religion (e.g. Marett 1914: xxxii-xxvii, xxxi). 
By the 1930s the evolutionist paradigm had been overturned, within anthropology at least, and in 1940 Firth published an article in which he showed that among the Tikopia people he had worked with in the southeastern Solomons, mana (/manu) was 'not spoken of as a universal force inhering in all natural objects' (Firth 1940: 505) nor as a 'metaphysical abstraction' of any kind (496). Rather, it is:

connected with the personality of human beings, and is exercised through human agencies... The native view of manu may be regarded as an element in a theory of human achievement. Its thesis is that success above a certain point, the 'normal', is spirit-given. It connects an end-product empirically observed with a set of human desires by a theory of spirit-mediation and a technique of verbal utterance. (Firth 1940: 505)

More verb-like than noun-like in many of its uses, the Tikopia term manu is in at least some contexts best translated as to 'be effective' or to 'be efficacious' $(499,506)$.

Keesing (1984) took Firth's critique further by showing that similar conclusions to the ones that Firth had reached about Tikopia (a Polynesian language) could be drawn for a wide range of other languages within the Oceanic group of the Austronesian family languages (of which the Polynesian are a sub-group, see Figure 10). Through a detailed survey of Oceanic languages, Keesing showed that although cognate terms for mana were widespread among them, these had a much wider range of meanings than had been allowed for by Codrington et al., and that, just as Firth had found for Tikopia, these tended to cluster more around a notion of efficaciousness of human agency in specific contexts rather than of generalised supernatural power or influence. 


\section{Proto Austronesian}

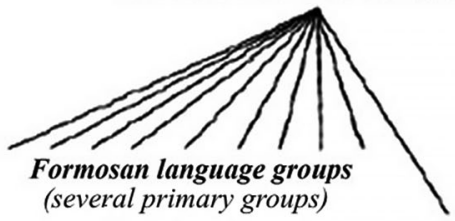

\section{Proto Malayo-Polynesian (MP)}

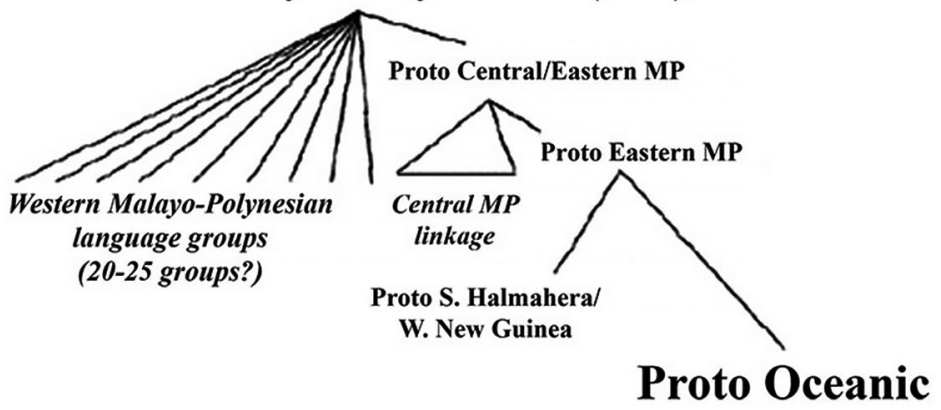

Figure 10. The high-order subgroups of Austronesian.

Source: Malcolm Ross, used with permission.

Used in the latter sense, the word mana had become, as Firth put it, 'a technical term describing a specialized abstraction of the theoretical anthropologist' which had 'little in common with the same term used within native phraseology' (487). ${ }^{1}$ In the 75 years since Firth's article was published, mana has disappeared as a technical term in anthropology but gained a wider currency in a lay version of the older anthropological sense, that is, as the Concise Oxford puts it: 'power, authority, prestige; supernatural or magical power' (see the chapters by Morgain and by Golub and Peterson in this volume).

Following up on Keesing's study of "mana words within Oceanic Austronesian languages, ${ }^{2}$ a considerable amount of relevant new evidence has been turned up by specialists in the comparative study of those languages. Drawing on an even wider sample than Keesing had, Robert Blust (2007) showed that in many Oceanic languages there

1 Firth (1940: 487) points out that this possibility was explicitly acknowledged by at least two of those anthropologists, Marett and Hocart.

2 In line with standard practice within comparative-historical linguistics, the star before mana here indicates that the starred word is one that, on the basis of comparative evidence, is posited as the word in the original ancestral language (Proto-Oceanic Austronesian) from which all the cognates in the presently attested Oceanic languages have descended. 
were cognate words meaning 'thunder' and 'wind'. On that basis he argued that "mana did not originally refer to spiritual or supernatural power that could be possessed by humans, but rather to powerful forces of nature that were conceived as the expressions of invisible supernatural agency. Based on the present-day distribution of *mana cognates and their meanings, he argued that 'as Oceanic-speaking peoples spread eastward, the notion of an unseen supernatural agency became detached from the physical forces of nature that had inspired it and assumed a life of its own' (404).

Building on Keesing's and Blust's arguments, Juliette Blevins (2008) expands their comparative base to include not only Oceanic languages, but two other higher-level sub-groupings of the Austronesian family: Central Malayo-Polynesian and South Halmahera/West New Guinea (see Figure 10). In other words, she claims to have found mana cognates not only in the Pacific and New Guinea but also within parts of Eastern Indonesia and Timor (Figure 11). She traces these back to a posited Proto Central-Eastern Malayo-Polynesian (PCEMP) word *mana, to which she attributes the meaning 'supernatural power, associated with spirits of the ancestors and the forces of nature' (Blevins 2008: 253). This meaning is consistent with the one that Blust posits for Proto Oceanic, but goes beyond it in its reference to ancestral spirits. Words that Blevins cites from Oceanic languages that exemplify the meanings relating to ancestral power (all from the southeastern Solomons) are shown in Table 2.

Table 2. Mana words from southeastern Solomons languages relating to ancestors and inheritance.

\begin{tabular}{|l|}
\hline TOQABAQITA \\
\hline mamana 'be true, real, fulfilled; be successful (of a man); impart spiritual or magical power' \\
\hline Mamana-a 'blessing, prosperity; ancestrally conferred power' \\
\hline KWAIO \\
\hline nanama 'be effective, fulfilled, confirmed, realised; of ancestor, support, protect, empower' \\
\hline nanama-fa- 'of ancestor, support, protect, empower (a person)' \\
\hline Nanama-nge' e-ni 'of ancestor, support, protect, empower (a person)' \\
\hline GELA \\
\hline $\begin{array}{l}\text { mana '[be] efficacious; from spiritual power, obtained from charms, prayers, intercourse } \\
\text { with [ancestors or spirits]' }\end{array}$
\end{tabular}

Source: From Juliette Blevins. 2008. Some comparative notes on Proto-Oceanic *mana: Inside and outside the Austronesian family. Oceanic Linguistics 47: 253-74, p. 264. 


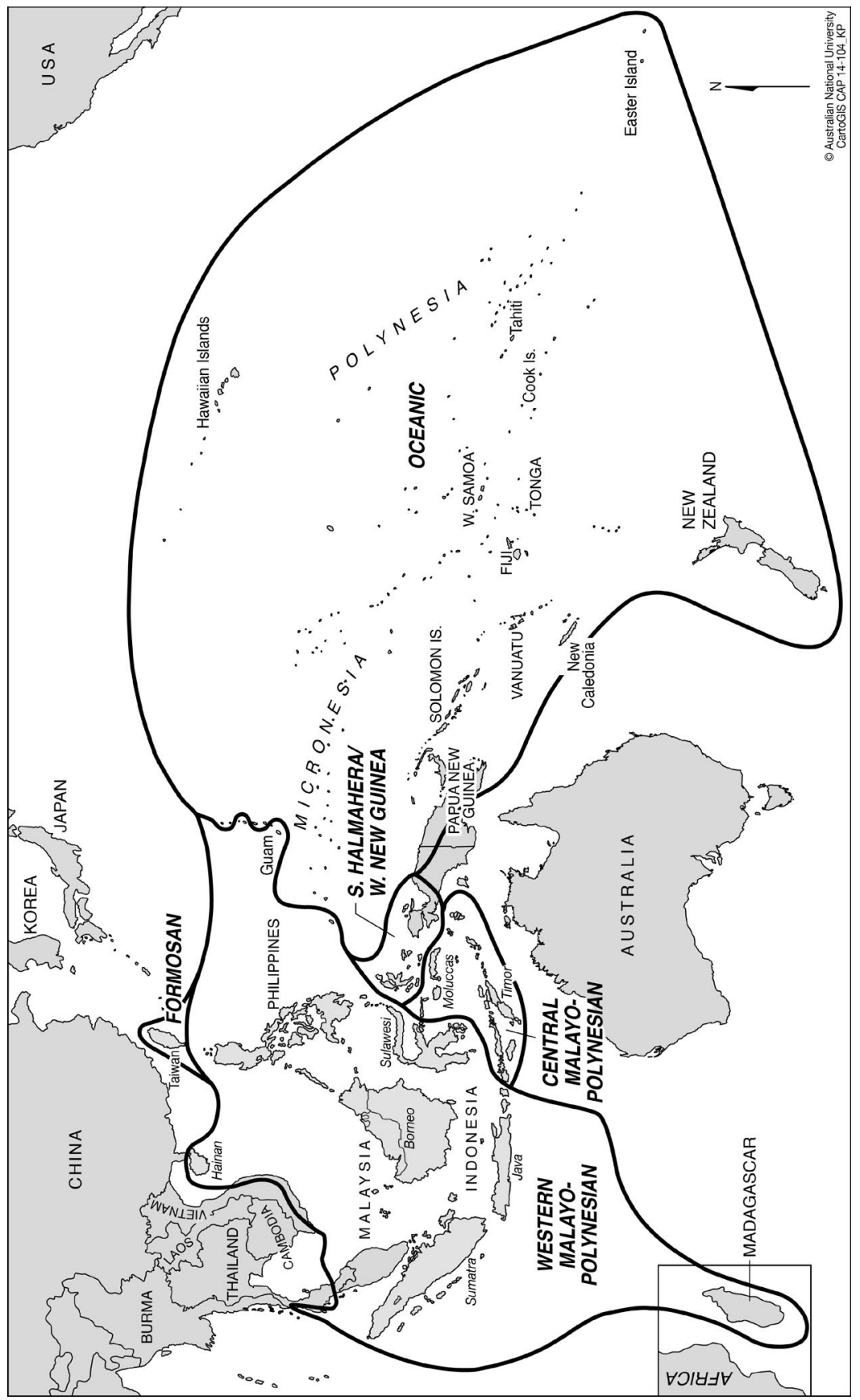

Figure 11. Approximate boundaries of the major subgroups of Austronesian.

Source: (C) The Australian National University, CAP CartoGIS. 
Another way in which Blevins goes beyond Blust's account is by relating the posited "mana word to another word ${ }^{*}$ mana $(q),{ }^{3}$ which is attested within Austronesian languages of the Western MalayoPolynesian (WMP) group (see Tables 2 and 3), to which she attributes the meaning 'inherit(ance) from ancestors'. Based on the overlap between this meaning and that of PCEMP *mana as shown by the boldfaced parts of the definitions in Table 2, Blevins traces both WMP ${ }^{*}$ mana $(q)$ and PCEMP *mana to a single posited word *mana $(q)$ at the level of Proto Malayo-Polynesian. In line with this scenario, Blevins (2008: 270) tentatively proposes the set of forms and meanings within the various subgroups of the Malayo-Polynesian that are shown in Table 3.

\section{Table 3. Blevins' proposed set of etymologies for *mana(q) words in Malayo-Polynesian languages.}

\begin{tabular}{|l|l|}
\hline$(12)$ & $\begin{array}{l}\text { PMP *mana }(q) \text { 'supernatural power, associated with spirits of the ancestors and } \\
\text { the forces of nature; inherit(ance) from ancestors, including qualities of spirit or } \\
\text { body, customs and laws' }\end{array}$ \\
\hline $\begin{array}{l}\text { PWMP *mana }(q) \text { 'inherit(ance) from ancestors, including quality of spirit or body } \\
\text { that one has from one's forebears' }\end{array}$ & $\begin{array}{l}\text { PCEMP *mana 'supernatural power, associated with spirits of the ancestors and } \\
\text { the forces of nature' }\end{array}$ \\
\hline & $\begin{array}{l}\text { PCMP *mana 'spirit, spiritual power, ancestor spirit' } \\
\text { the forces of nature' }\end{array}$ \\
\hline $\begin{array}{l}\text { PSHWNG *man- 'bird; male, man; special power', } \\
\text { POc *mana 'supernatural power, associated with spirits of the ancestors and the } \\
\text { forces of nature' }\end{array}$ \\
\hline
\end{tabular}

Source: From Blevins, Some comparative notes on Proto-Oceanic *mana, p. 270. Abbreviations are: PMP, Proto Malayo-Polynesian; PWMP, Proto Western MalayoPolynesian; PCEMP, Proto Central/Eastern Malayo-Polynesian; PCMP, Proto Central Malayo-Polynesian; PEMP, Proto Eastern Malayo-Polynesian; PSHWNG, Proto South Halmahara/West New Guinea; POc, Proto Oceanic.

Casting her comparative net even more widely, drawing in part on Aletta Biersack $(1995,1996)$, Blevins points to the presence of words of similar or identical form and closely related meanings among nonAustronesian languages of New Guinea. Her list of them is shown in Table 4.

3 The (q) in this form stands for a uvular or glottal stop that occurs in some of the putatively related words within the cognate set and not in others. 
Table 4. Blevins' list of 'mana lookalikes' in non-Austronesian languages of the New Guinea area.

\begin{tabular}{|c|c|c|c|c|}
\hline LANGUAGE & AREA & DATA SOURCE & LOOKALIKE & GLOSS \\
\hline Warembori & $\begin{array}{l}\text { Yapen- } \\
\text { Waropen, } \\
\text { Jayapura }\end{array}$ & Donohue (1999) & $\mathrm{ma} / \mathrm{mana}$ & 'good' \\
\hline Ipili-Paiela & Enga Province & $\begin{array}{l}\text { Biersack } \\
\text { (1996:90-91) }\end{array}$ & mana & 'knowledge' \\
\hline Enga & Enga Province & Lang (1973) & mána & $\begin{array}{l}\text { 'instruction, rule, } \\
\text { way of doing' }\end{array}$ \\
\hline $\begin{array}{l}\text { Kyaka } \\
\text { Enga }\end{array}$ & $\begin{array}{l}\text { W. Highlands } \\
\text { Province }\end{array}$ & $\begin{array}{l}\text { Draper and } \\
\text { Draper (2002) }\end{array}$ & $\begin{array}{l}\text { mana } \\
\text { mana makande }\end{array}$ & $\begin{array}{l}\text { 'mind, learning, } \\
\text { capacity' } \\
\text { 'habit, custom, } \\
\text { trend' }\end{array}$ \\
\hline Melpa, Nii & $\begin{array}{l}\text { Mt. Hagen, W. } \\
\text { Highlands }\end{array}$ & Strauss (1990) & $\begin{array}{l}\text { man } \\
\text { man-ek }\end{array}$ & $\begin{array}{l}\text { 'powerful, might: } \\
\text { working through } \\
\text { magic' } \\
\text { 'powerful, effective } \\
\text { speech' }\end{array}$ \\
\hline \multirow[t]{5}{*}{ Middle Wahgi } & \multirow[t]{5}{*}{$\begin{array}{l}\text { Mt. Hagen, } \\
\text { W. Highlands } \\
\text { Provice }\end{array}$} & \multirow[t]{5}{*}{ Ramsey (1975) } & $\begin{array}{l}\operatorname{man} \\
\operatorname{man}(\mathrm{e}-/ \text { to- })\end{array}$ & $\begin{array}{l}\text { 'n. ritual' } \\
\text { 'v. to perform a } \\
\text { ritual' }\end{array}$ \\
\hline & & & $\begin{array}{l}\text { kunje man (e-/ } \\
\text { to-) }\end{array}$ & $\begin{array}{l}\text { 'v to work good } \\
\text { magic; especially } \\
\text { the ritual by which } \\
\text { one works magic' } \\
\text { (kanje 'magic, } \\
\text { done for the } \\
\text { purpose of helping } \\
\text { a person') }\end{array}$ \\
\hline & & & nu/man & $\begin{array}{l}\text { 'n. thought, mind, } \\
\text { will' }\end{array}$ \\
\hline & & & $\mathrm{ke} / \mathrm{man} \mathrm{yu}$ & $\begin{array}{l}\text { 'n. words of } \\
\text { instruction, spoken } \\
\text { request as to } \\
\text { the disposition } \\
\text { of one's goods } \\
\text { after death' (ke- } \\
\text { 'send', yu 'words, } \\
\text { language') }\end{array}$ \\
\hline & & & $\begin{array}{l}\text { mam/bnem } \\
\text { minman }\end{array}$ & $\begin{array}{l}\text { 'n. instructions, } \\
\text { customs, source' } \\
\text { 'n. spirit or soul of } \\
\text { living person' }\end{array}$ \\
\hline Duna & $\begin{array}{l}\text { S. Highlands } \\
\text { Provice }\end{array}$ & $\begin{array}{l}\text { Modejeska } \\
\text { (1977: 164) }\end{array}$ & mana & $\begin{array}{l}\text { 'custom, tradition, } \\
\text { instructions of the } \\
\text { elders' }\end{array}$ \\
\hline
\end{tabular}




\begin{tabular}{|c|c|c|c|c|}
\hline LANGUAGE & AREA & DATA SOURCE & LOOKALIKE & GLOSS \\
\hline Huli & $\begin{array}{l}\text { S. Highlands } \\
\text { Province }\end{array}$ & $\begin{array}{l}\text { Glasse (1965), } \\
\text { Goldman (1993) }\end{array}$ & mana & $\begin{array}{l}\text { 'custom, way, } \\
\text { norms, laws; myth' }\end{array}$ \\
\hline Kewa & $\begin{array}{l}\text { S. Highlands } \\
\text { Province }\end{array}$ & $\begin{array}{l}\text { Franklin and } \\
\text { Franklin (1978) }\end{array}$ & mana ta & $\begin{array}{l}\text { 'to advise well, } \\
\text { give admonitions, } \\
\text { instructions' }\end{array}$ \\
\hline Pinai-Hagahai & $\begin{array}{l}\text { Madang } \\
\text { Province } \\
\text { border }\end{array}$ & $\begin{array}{l}\text { Biersack } \\
(1996: 90-91)\end{array}$ & mana & 'to learn' \\
\hline $\begin{array}{l}\text { Hua (aka } \\
\text { Yagaria) }\end{array}$ & $\begin{array}{l}\text { E. Highlands } \\
\text { Province }\end{array}$ & Haiman (1991) & $\begin{array}{l}\text { manu } \\
\text { manu gzo- }\end{array}$ & $\begin{array}{l}\text { 'n. last wishes, } \\
\text { will' } \\
\text { 'v. singing' }\end{array}$ \\
\hline \multirow[t]{2}{*}{ Fore } & \multirow[t]{2}{*}{$\begin{array}{l}\text { E. Highlands } \\
\text { Province }\end{array}$} & \multirow[t]{2}{*}{ Scott (1980) } & $\begin{array}{l}\text { amaná/ne } \\
\text { amani/ne }\end{array}$ & $\begin{array}{l}\text { 'spirit of dead } \\
\text { person, departed } \\
\text { soul' } \\
\text { 'demon, elf, } \\
\text { spirit, spiritual, } \\
\text { supernatural' }\end{array}$ \\
\hline & & & $\begin{array}{l}\text { amani } \\
\text { kámanane }\end{array}$ & $\begin{array}{l}\text { 'folk-lore, fable, } \\
\text { myth, legend' } \\
\text { (cf. kámanane } \\
\text { 'talk, speech, } \\
\text { language, story, } \\
\text { conversation, } \\
\text { words') }\end{array}$ \\
\hline Kâte & $\begin{array}{l}\text { Morobe } \\
\text { Province }\end{array}$ & $\begin{array}{l}\text { Flierl and } \\
\text { Strauss (1977) }\end{array}$ & $\mathrm{ma} / \mathrm{mana}$ & $\begin{array}{l}\text { 'v/n. the act of } \\
\text { hearing, feeling, } \\
\text { understanding, } \\
\text { knowing; } \\
\text { knowledge' }\end{array}$ \\
\hline Selepet & $\begin{array}{l}\text { Morobe } \\
\text { Province }\end{array}$ & $\begin{array}{l}\text { McElhanon and } \\
\text { McElhanon } \\
\text { (1970) }\end{array}$ & man-manman & $\begin{array}{l}\text { 'to live, practice (a } \\
\text { custom)' } \\
\text { 'life-sustaining } \\
\text { power' }\end{array}$ \\
\hline Buin & Bougainville & Laycock (2003) & $\begin{array}{l}\text { mana }(\mathrm{N} .) \\
\operatorname{mara}(\mathrm{S} /)\end{array}$ & $\begin{array}{l}\text { 'n. spirit, devil, } \\
\text { nonhuman } \\
\text { creature' }\end{array}$ \\
\hline Siwai (Motuna) & Bougainville & Onishi (2002) & $\begin{array}{l}\text { mo:no } \\
\text { manu/nu }\end{array}$ & $\begin{array}{l}\text { 'magical corner of } \\
\text { taro garden' } \\
\text { 'wealth, } \\
\text { possession' }\end{array}$ \\
\hline
\end{tabular}

Source: From Blevins, some comparative notes on Proto-Oceanic *mana, p. 267.

Blevins (2008: 266) points out that in two of the languages on her list, Middle Wahgi and Selepet, the range of senses of the words in question relate to both of the ones that she has posited for Proto Malayo-Polynesian, namely 'inherited supernatural power' and 'inherit(ance) from ancestors'. Given the range of these and other 
attested senses on her list, and the geographical distribution of the languages on it, she tentatively proposes that the apparent similarities between these 'mana lookalikes' in Papuan languages and mana $(q)$ words in Austronesian ones are the result of borrowing from the latter into the former. Although this proposal is an interesting one, there are two aspects of it that seem difficult to reconcile with current understandings of the prehistory of Papuan languages.

The first is that, as Blevins realises, there is another plausible source besides borrowing from Austronesian for most or all of the 'mana lookalikes' shown in Table 4. Most of them arguably belong to a group of related languages, the Trans-New Guinea (TNG) phylum, the geographic spread of which is shown in Figure 12. In a recent unpublished paper - an earlier version of which is cited by Blevins ${ }^{4}-$ one of the leading Papuanists, Andrew Pawley, presents two distinct cognate sets, one of which he assigns to Proto TNG * $m V n a^{5}-$ 'be, exist, live' and the other to Proto TNG *mana 'instructions, customary practices, e.g. ritual, taboo, rule' (Pawley 2013: 9-10, 54), in addition to which he now says he "probably should have added "speech, talk" to the range of glosses' (personal communication, September 2013). As Pawley also points out, the inference that these are distinct cognate sets is supported by the fact that 'reflexes occur as contrasting forms with contrasting meanings in the same low order subgroups (e.g. Chimbu-Waghi, Kainantu-Goroka, Rai Coast), and, in one case, in the same language: Kobon mund- "be, live" ( $\left.{ }^{*} \mathrm{n}>\mathrm{nd}\right)$ and manø "speech, talk, language"".

The meanings of most of the forms in Table 4 relate closely to ones that Pawley has posited for * $m$ Vna and *mana in Proto Trans-New Guinea. If that is indeed where they come from then there is no need to attribute them to borrowing from Austronesian languages. As has been pointed out to me by Blevins (personal communication, 16 January 2014), some of the languages represented in Table 4-Warembori, Pinai-Hagahai, Buin and Siwai-are not classified as Trans-New Guinea ones. All of those languages are located in close proximity to Austronesian ones. For the words shown on the table from them, if their meanings are

4 In the 2008 version of this paper cited by Blevins (2008: 263), Pawley had posited a single original TNG word *mana whereas he now posits two distinct ones with different meanings as described below.

5 The $\mathrm{V}$ in this form designates a variable vowel in the first syllable, as distinct from the invariant $a$ in both syllables of *mana. 
taken to be close enough to the others' to justify positing a common source (a debatable matter), it would seem equally plausible to attribute them to diffusion into those languages from Austronesian or from Trans-New Guinea Papuan. Regarding the words from other languages represented on the list, given their wide distribution across the TNG region-including highland areas which remained largely isolated from the outside world (including the Austronesian one) until the 1930s - it seems more plausible to attribute them to shared retention from Proto TNG.

Second, even at the level of Proto-Oceanic Austronesian, if borrowing was involved in the transmission of *mana, I can see no reason to assume that its direction must have been from Austronesian into Papuan. As Blevins realises, the TNG phylum is likely to be much older than the Malayo-Polynesian group of Austronesian languagesindeed, much older than the Austronesian family itself (Pawley 2005: 9697). ${ }^{6}$ If the similarity of form and partial overlap in meaning between Austronesian and Papuan mana words is due to borrowing it seems possible that the borrowing could have gone in the opposite direction to the one proposed by Blevins, that is, from Papuan languages spoken in the Bismarck Archipelago to early forms of Oceanic Austronesian, including Proto-Oceanic, that are thought to have been spoken there before the movement of Oceanic language speakers into the southwest Pacific (Ross, Pawley and Osmond 2003: 15; Pawley 2008). ${ }^{7}$

\section{Mana and pawa}

In order to pursue the question of mana in the expansive way that is envisioned by the editors and contributors to this volume, it is important to examine not only concepts and phenomena associated with words that are etymologically related in the ways discussed above, but also to consider related concepts for which the words may differ in form. In this section of the chapter I do both of those things with respect to

6 Based on a wide range of linguistic and archeological evidence, Pawley (2008) dates Proto Oceanic at 3400-3100 BP. Pawley (2012) places Proto Trans New Guinea at 10,000-7000 BP.

7 If this is what actually happened, the borrowed word would have given rise only to ProtoOceanic * mana, not to the *mana $(q)$ that is found in Western Malayo-Polynesian languages. Such a scenario is incompatible with Blevins' attempt to trace both Oceanic * mana and PWMP * mana(q) to a common proto-form, but compatible with the more common position among Austronesianists that the two words are historically distinct and cannot be traced to a common source. 
the Ku Wuru region of the Western Highlands Province of Papua New Guinea, where Francesca Merlan and I have been doing anthropological and linguistic fieldwork on various projects since 1981. Ku Waru lies roughly in the middle of the TNG region shown in Figure 12.

There are four words we know of in the Ku Waru language that resemble one or more of Blevins' TNG 'mana lookalikes' in meaning and sound (although none of them exactly). One is mani, which combines with ung (word, discourse) to mean 'advice', 'warning', 'teaching' or 'lesson', and in a kind of prototypical usage refers specifically to general advice passed on by fathers to their sons. ${ }^{8}$ This word is clearly similar in meaning to other words on Blevins' list which could be traced to Pawley's posited TNG proto-form * mana. ${ }^{9}$

The second notable mana lookalike is man, which combines with the verb to- 'hit, do' to mean something like 'perform a religious ritual', and is used both in reference to the Catholic mass ${ }^{10}$ and pre-existing non-Christian rituals such as the female spirit cult (Strathern 1970) and sacrifice to ancestors (Rumsey 2008: 458-60). This word is clearly cognate to man and man to- in the fairly closely related language Middle Wahgi, and probably to man in the even more closely related language Melpa, but does not correspond closely in meaning to any of the other words on Blevins' list.

The other two Ku Waru words that resemble ones on Blevins' list are numan 'mind', 'will', 'intention' and mini 'soul', 'spirit'. We do not regard the former as sufficiently close in meaning or the latter as sufficiently close in form to be identified either with Proto TNG "mana or " $m V n a$, or with any of Blevins' posited proto-forms as shown in Table 3 (notwithstanding the inclusion on her list of the Middle Wahgi word numan, which is clearly cognate to Ku Waru numan, and minman, which is a possible cognate of Ku Waru mini).

8 As explained to me by our long-term Ku Waru friend and assistant Andrew Noma (in May 2014 as I was revising this paper during the course of fieldwork in PNG): 'When our father is about to die he will tell us things like “Don't get angry with your brother; be careful not to eat poison; don't touch anything that belongs to our enemies; always help out with contributions of pigs and money when your people are trying to settle a dispute; don't beat your wife or they might poison you."'

9 It is closest in meaning to words of the form mana in Kewa, Huli, Enga and Ipili. In order to establish it as a cognate of those words, with a presumed common proto-form * mana, one would have to account for why its final vowel is $i$ rather than $a$.

10 It is not used in reference to Lutheran services, which are called mis, or to other Protestant services, which are called by the Tok-Pisin derived term lotu. 
5. MANA, POWER AND 'PAWA' IN THE PACIFIC AND BEYOND

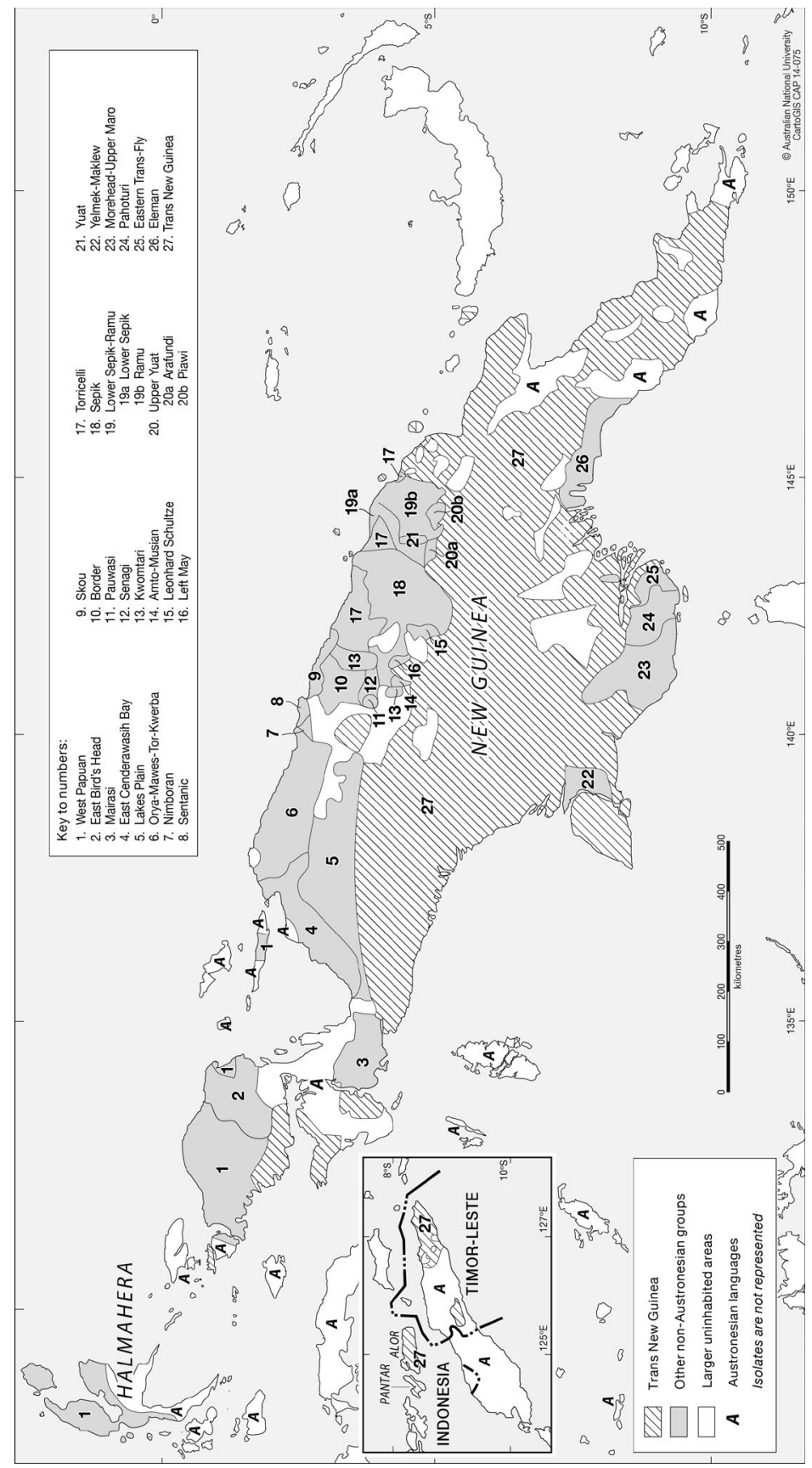

Figure 12. The Trans New Guinea Phylum and other language groups in New Guinea and environs.

Source: () The Australian National University, CAP CartoGIS. 
Clearly none of the Ku Waru words discussed above is at all close in meaning to the canonical one of 'efficaciousness' that Keesing attributes to Oceanic Austronesian. The Ku Waru word that comes closest to that sense is pawa - a word that has been borrowed into the language from the PNG lingua franca Tok Pisin. Although the word derives ultimately from English 'power' it is in some ways closer in meaning to Oceanic mana as discussed by Firth and Keesing. To see how, let us consider two examples of its use in context.

The first example comes from a speech given in 1983 at a ceremonial exchange event that is discussed in detail in Merlan and Rumsey (1991). The speech concerned a remarkable event that had taken place in 1982. A war had broken out between two groups of tribes in the region. Before anyone was killed, the war was stopped by the intervention of a women's work group who marched out on to the battlefield between the opposing sides carrying the national flag and exhorted the combatants to call off the fight and take their weapons back home. Equally remarkably, the men did as they were told and did not do battle again for the next 23 years.

The women's actions included a payment to the men on both sides in the form of cash, trade goods and produce from the work group's market gardening activities. Having made that payment, according to local protocols, the women's group had to be given a return payment from both of the combatant sides at the exchange events which were held for the payment of compensation among the allied groups. At one such event, in August 1983, the following speech was made by a forceful leader of the women's group, Mijiyl Pokea:

(1) na ing mare awuntipa nyi naa nyibu

I will not speak at length

pilis matres na kansil na ...

the village magistrates and councillors and ...

pilis matres yabu lupu lupu ing ilyi-nga na-ni age nyikir

for the village magistrates' and others' invitation I say thanks

Kansil-ayl-nge ul ilyi tepa kodupa lyim

the Councillor [Kujilyi] invited us 
(5) ilyi-nga na age anum-uyl nyikir

and for that, I say, thank you very much

ya noi el tiring ilyi-nga ya ab anum mel koltal

they fought down there and so, just a few older women

kongun kubilek tiring

were working at first

tek molku-kin ilyi-nga puk noi kubu tiring

they were (working), and going down they worked at Kubu

[in Tilka territory]

noi kalyke ya med palimung kolya-ma-nga tiring ilyi-nga

down at Kailge and here at Palimung they were working

(10) ya kolya-ma-nga el-ma naa tiang

'let them not have any fights around here'

ab-ayl kongun-ayl todul pupiyl nyik pamul

saying, 'let the women's work grow strong, let's go'

wany-ayl mek ok eni-n brukim tiring

bringing the flag they stopped it

(from transcript in Merlan and Rumsey 1991: 171-72)

Mijiyl's speech was followed by one from a leading 'big-man', Kopia Mel, which included the following words:

wanya plak-ayl puk mek ok moduring ilyi-o

they went and placed the flag there

gavman-nga el masket kare mek pu naa puring, mol

they were not carrying government 'muskets', no!

gavman-nga yunifom-te pi naa pirim mol ilyi-o

they were not wearing government uniforms, no!

ilyi ab mel pangi-te nyi-pilyik ab-nga pawa pirim.

you may think women are a weak reed but they had determination

(from transcript in Merlan and Rumsey 1991: 178)

Note that, whereas Mijiyl (in line 11) has used the indigenous Ku Waru word todul 'strong' in reference to the work of the women's group, Mel (in the last line) uses the Tok Pisin derived word pawa in reference 
to their strength. This is typical of current Ku Waru usage in that although the word todul can be used as a noun for 'strength' ${ }^{11}$ in fact it seldom is. Instead people use pawa.

A typical Ku Waru use of the word pawa occurs in the last line of the excerpt from Kopia Mel's speech. In our 1991 transcript as shown above we translated the word as 'determination', but when considered in relation to Firth's and Keesing's expositions as discussed above and other cases discussed in this volume, an equally appropriate translation would have been mana. What makes it so is that, as emphasised by Mel and other speakers who commented on the women's successful action (see Merlan and Rumsey 1991: 172-74), it was not the result of any pre-given capacities or powers, but a matter of surprising efficacy as revealed through the outcome of the action.

Now let us consider another example from 30 years later in the same community of Ku Waru people. The long peace (by local standards!) that was initiated by the women's battlefield intervention ended in 2005 when fighting broke out over a poisoning accusation. The details are too complex to go into here (see Rumsey 2009); suffice it to say that the men who were held responsible for the poisoning were from Tilka, a small tribe whose territory was adjacent to that of the Kopia tribe, to which the victims of the alleged poisoning belonged. In 2005 the Kopia and some of their allies invaded Tilka territory, drove them away from it and burned all the houses at the main Tilka settlement. Together with their much larger and more powerful allied tribe the Kulka, the Tilka then retaliated by invading Kopia territory and doing the same. The Tilka did not then attempt to reoccupy their territory but instead went back to live with Kulka and elsewhere. Nor did the Kopia attempt to occupy Tilka territory en masse. Rather, a few Kopia and allied families that included in-married Tilka women began coming to the area and cultivating gardens there. After the fighting stopped in 2007, one of those families built a house at the erstwhile Tilka settlement. In 2012, a Tilka family came back and did the same. The two families got along well, the Kopia one even feeding the Tilka one from their by then well-established sweet potato gardens while the Tilka family waited for theirs to come in. In 2013 a young

11 A spontaneous (as opposed to elicited) example we recorded in 1983 is olyo-nga todul-te mol, 'we have no strength/power' (from a dispute transcript in Merlan and Rumsey 1986: 158, line 1374). 
man from the Tilka family died, for reasons unrelated to the earlier fighting. A funeral was held and the family buried the man near the house that they had built. This was a provocative move, since among $\mathrm{Ku}$ Waru people as elsewhere in the PNG Highlands, burying one's dead constitutes a strong claim to the land on which it is buriedstronger even than building a house on it or planting gardens there.

In response, shortly after the burial some men from the Kopia alliance came in the night, dug up the casket and left it beside the grave. The next night some other men from the Kopia alliance came and buried it again. These three actions - the burial, exhumation and reburialfor the first time forced the Kopia alliance to confront an issue that had been left unresolved until then: Would the Tilka be allowed to reoccupy their erstwhile territory, and if so, when? The question had been much discussed, at least as far back as 2009, at a peace-building workshop in which I had participated, which was the first time since the new fighting that leaders from both sides had met with each other face-to-face (see Rumsey 2009: 9-12). Some people from the Kopia alliance had been completely opposed to allowing the Tilka to move back. Others had said that in the interest of long-term peace the Tilka should be allowed to do so, but given the still-powerful memories of the poisonings and deaths in the fighting, more time would have to be allowed to pass before the move could be allowed. Now, six years after the cessation of fighting, a decisive move had been taken by the Tilka, and contradictory counter-moves taken by members of the Kopia alliance. Which position would prevail?

Over the next few weeks, after the reburial by those on the peacemaking side of the issue, it became clear that they had won the day. There were no further attempts to exhume the body or force the Tilka to move it, and by the time Francesca and I returned to Kailge in August 2013 the burial was being treated as a fait accompli, along with a general acceptance that the Tilka would eventually be allowed to reoccupy their land. When we returned in January 2014 and visited Tilka territory we found that several more Tilka had returned, all of whom were related to Kopia, either by marriage or through their mothers. By May 2014 most of Tilka territory had been reoccupied by Tilka people, not all of whom were related to Kopia or any of the other groups who had fought against them. 
During the course of our January-February 2014 fieldtrip, in a discussion that I had with a Kopia woman named Kuin about that train of events and its outcome, when referring to the reburial and the men who had carried it out she said 'eni-nga pawa pirim' ('they had pawa'). In response to my questions about what she meant by that, Kuin and others made it clear that the reburialists did not have any way of compelling people to side with them. Rather, they had made a bold move which had impressed people with its decisiveness and had apparently rested on a correct judgment that the conditions were right for its acceptance. In all those respects, the reburialists' action and its efficacy resembled that of the women who had intervened on the battlefield 30 years before. And here again, as in that case, the local commentators' use of the word pawa in reference to the action entails a sense of retrospectively revealed efficaciousness that resonates with the understanding of mana that was proposed by Firth and Keesing and is exemplified elsewhere in this volume.

This is not to say that all uses of the word pawa in Ku Waru are like that, or that the word is never used by Ku Waru people in the more substantivising sense that Keesing claims is absent from Oceanic Austronesian uses of "mana words. We came across a striking counterexample early in the course of fieldwork when a Ku Waru woman who was an avid card player found out that we had originally come to Australia from the United States, and had family and other contacts there. She told Francesca that she had heard about a kind of object or substance called Amerikan pawa which gave its possessor the ability to win every time at card games, and asked us if we could arrange to have some of it sent to us for her. To her disappointment we had to tell her that we knew of no such thing. (It is not clear whether she believed us, as she made the same request again to Francesca as we were about to leave.)

\section{Mana, pawa and approaches to comparison}

So far in this chapter I have discussed various understandings of mana as a word or set of presumably related words in Austronesian and Papuan languages, and the Tok-Pisin-derived word pawa within 
$\mathrm{Ku}$ Waru that is used in comparable ways. ${ }^{12}$ What I will do in this final section is to engage in a meta-level comparison to consider what is involved in comparisons of both of those kinds of cognate words and of similar meanings and compare them with another kind of comparison that has been brilliantly applied to areas of the Western Pacific, namely, the one used by Marilyn Strathern in her book The Gender of the Gift (1988).

As for the former, non-Strathernian kind of comparison, what I and other contributors to this volume have done is in some ways similar to what Raymond Williams did in his 1976 volume Keywords: A Vocabulary of Culture and Society. Starting with a number of 'keywords' which are much used within a particular discursive domain - in his case discourse about culture and society-Williams treated them not as terms to be defined but rather as sites of contestation across that domain. This volume does the same thing, not with respect to a whole analytical vocabulary, but with respect to the single term mana, which has been used both as term of art within anthropology and religious studies, and from the viewpoint of its vernacular uses within a range of languages and sociocultural contexts across the Pacific and beyond. Just as in Williams' approach, one thing this allows for is a full consideration of contestation and diversity in the uses of the term within given languages at particular locales, across more extensive regions within which it has circulated, and in the ways that those vernacular uses have been understood by various analysts.

Before turning to the comparison between those approaches to comparison and Strathern's, let us first briefly consider the diversity that is revealed by a keywords approach to a single word that is especially relevant for this chapter and the volume as a whole, namely 'power'. This is a word which even in strictly Anglophone discourse has been what Steven Lukes (1974) has referred to as an 'essentially contested' one, as illustrated both by the entry on it in the New Keywords volume by Gregor McLennan, and more extensively by

12 Although I have discussed this word only with respect to Ku Waru, there is evidence for its use as a borrowed word within at least one other language in Papua New Guinea, Guhu-Samane, which is spoken in Morobe Province about $300 \mathrm{~km}$ to the east of Ku Waru. Based on her extensive linguistic-anthropological research there, Courtney Handman (personal communication, 10 September 2013) reports that the word pawa 'was everywhere in [Guhu-Samane]'. It is of course also an everyday word in Tok Pisin, in which context there are also interesting questions about its semantics vis-à-vis mana and 'power'. I do not discuss those here. 
Lukes in his 1986 anthology on the subject with readings from Max Weber, Jürgen Habermas, Georg Simmel, Michel Foucault, Bertrand Russell and others. Of particular relevance here is Hannah Arendt's view of power, which she sees as being inherently relational: 'Power corresponds to the human ability not just to act but to act in concert. Power is never the property of an individual' (Arendt 1986: 64).

Now let us consider the approach to comparison that is taken in this volume in relation to the one taken by Marilyn Strathern in The Gender of the Gift. Interestingly, in that book, unlike this one, none of the key terms in the analysis is drawn from any indigenous language of the region. Instead, Strathern uses what she calls 'the language of Western analysis' in a way that she hopes will 'expand its metaphorical possibilities' by using it in what she calls 'incidental juxtaposition' to what she takes to be 'Melanesian' understandings. One such term is 'power', to which Strathern devotes a full chapter (1988: 98-132). Although she does not refer to Firth or Keesing, her discussion is reminiscent of their accounts of mana in that it stresses efficacy and the fact that it can only ever be retrospectively revealed. More particularly, Strathern stresses the importance for 'Melanesians' of the way in which efficacy is revealed in the reactions of other people $(119,288,294)$, an idea which is consistent with her claims that 'the acting subject or agent is construed in these [Melanesian] systems as a pivot of relationships' and 'an agent is one who acts with another in mind' (272).

The convergence between Firth, Keesing and Strathern here seems telling. It suggests that, notwithstanding Strathern's disavowals on this point, the juxtaposition of a 'western' term such as 'power' with a 'Pacific' one such as mana need not be merely 'incidental' or 'metaphorical'. To see why, let us consider the fuller form of Strathern's claims from which the quotes near the beginning of the previous paragraph are taken:

All I have done is to make explicit such implicit cultural comparisons as are entailed in the incidental juxtapositions of deploying one language as the medium in which to reveal the form that another, were it comparable, might take.

Yet this also makes comparability disappear. Languages themselves are not generalized but specific phenomena. In expanding the metaphorical possibilities of the specific language of Western analysis, it can only be its own metaphors that I utilize. (Strathern 1988: 343) 
For present purposes, the problem with this formulation is that it is too homogenising in what it assumes about the specificity of given 'languages' and too categorical in what it assumes about the differences between them. The first point is exemplified by my discussion of the 'essentially contested' nature of the term 'power' even within 'western' discourse, by the astonishingly wide range of takes on mana from around the world as shown by this and other chapters, and by the range of uses of the word pawa in Ku Waru, which includes both substantivising and non-substantivising ones. The second point can be illustrated by noting the overlap between Hannah Arendt's inherently relational (albeit 'western') view of power and the similarly relational senses of mana that were emphasised by Firth and Keesing and are also evident in the Ku Waru uses of pawa discussed in this chapter. At a more general level, the problem can be illustrated by noting that Strathern's treatment of the premise that 'an agent is one who acts with another in mind' as a specifically 'Melanesian' one is ill-founded. Something like that premise is actually shared by some 'western' theoretical accounts of agency (e.g. Gilbert 2000, Tuomela 2003) and in lay understandings of it as well, as reflected for example in the Merriam Webster online dictionary's first-listed definition of 'agent' as 'a person who does business for another person: a person who acts on behalf of another'.

The upshot of these considerations is that rather than treating the comparative exercise as one that takes place across different worlds, with 'incidental', 'juxtapositional', or 'metaphorical' kinds of understanding as the only ones that are possible between them (as opposed to some presumably more direct kind that is possible within them), it is more appropriate to treat the exercise as one that takes place within a single intercultural field within which terms and multiple forms of understanding circulate and interact with each other. The (mana-like?) efficacy of such an approach to comparison is well exemplified by the explorations of mana terms in this volume, by the actual results of Strathern's comparison framed in terms of 'power' (as distinct from her methodological characterisation of it), and by the interesting way in which aspects of mana and 'power' come together in $\mathrm{Ku}$ Waru and wider Melanesian takes on 'pawa'. 


\section{Acknowledgements}

For their valuable comments on drafts of this chapter I would like to thank Juliette Blevins and Francesca Merlan. For their helpful responses to email queries about parts of it, I thank Courtney Handman, Andrew Pawley and Malcolm Ross. Thanks also to Matt Tomlinson for his meticulous editing, and to participants at the Mana Conference who responded to the version I presented there.

\section{References}

Arendt, Hannah. 1986. Communicative power. In Power, ed. Steven Lukes, pp. 59-74. Oxford: Basil Blackwell.

Bennett, Tony, Lawrence Grossberg and Meaghan Morris (eds). 2005.

New Keywords: A Revised Vocabulary of Culture and Society. Malden, MA: Blackwell Publishing.

Biersack, Aletta (ed.). 1995. Papuan Borderlands: Huli, Duna, and Ipili Perspectives on the Papua New Guinea Highlands. Ann Arbor: University of Michigan Press.

- 1996. Word made flesh: Religion, the economy, and the body in the Papua New Guinea Highlands. History of Religions 36: 85-111.

Blevins, Juliette. 2008. Some comparative notes on Proto-Oceanic *mana: Inside and outside the Austronesian family. Oceanic Linguistics 47(2): 253-74.

Blust, Robert. 2007. Proto-Oceanic *mana revisited. Oceanic Linguistics 46(2): 404-23.

Codrington, R.H. 1881. Religious beliefs and practices in Melanesia. Journal of the Royal Anthropological Institute 10: 261-315.

- 1891. The Melanesians: Studies in their Anthropology and Folklore. Oxford: Clarendon Press.

Firth, Raymond. 1940. The analysis of mana: An empirical approach. Journal of the Polynesian Society 49(4): 483-510. 
Foley, William. 1986. Papuan Languages of New Guinea. Cambridge: Cambridge University Press.

Gilbert, Margaret. 2000. Sociality and Responsibility: New Essays in Plural Subject Theory. Lanham, MD: Rowman \& Littlefield.

Keesing, Roger M. 1984. Rethinking mana. Journal of Anthropological Research 40: 137-56.

Lukes, Steven. 1974. Power: A Radical View. London: Macmillan.

— (ed.). 1986. Power. Oxford: Basil Blackwell.

Marett, R.R. 1914 (2nd ed.). The Threshold of Religion. New York: Macmillan.

Merlan, Francesca, and Rumsey, Alan. 1986. A Marriage Dispute in the Nebilyer Valley, Western Highlands Province, Papua New Guinea. Studies in New Guinea Linguistics, Series A, No. 74, pp. 69180. Canberra: Pacific Linguistics.

- 1991. Ku Waru: Language and Segmentary Politics in the Western Nebilyer Valley. Cambridge: Cambridge University Press.

Pawley, Andrew. 2005. The chequered career of the trans New Guinea hypothesis: Recent research and its implications. In Papuan Pasts: Cultural, Linguistic and Biological Histories of the Papuan-speaking Peoples, ed. Andrew Pawley, Robert Attenborough, Jack Golson and Robin Hide, pp. 67-107. Canberra: Pacific Linguistics.

- 2008. Where and when was Proto Oceanic spoken? Linguistic and archaeological evidence. In Studies in Honour of Ülo Sirk, ed. Yury A. Lander and Alexander K. Ogloblin, pp. 47-71. München: LINCOM Europa.

- 2012. How reconstructable is Proto Trans New Guinea? Problems, progress, prospects. In Language and Linguistics in Melanesia, part I, ed. Harald Hammarström and Wilco van den Heuvel, pp. 84-164.

- 2013. Some trans New Guinea etymologies. Canberra: Department of Linguistics, School of Culture, History and Language, College of Asia and the Pacific, The Australian National University. Unpublished draft dated 8 September 2013. 
Pawley, Andrew, Robert Attenborough, Jack Golson and Robin Hide (eds). 2005. Papuan Pasts: Cultural, Linguistic and Biological Histories of the Papuan-speaking Peoples. Canberra: Pacific Linguistics.

Ross, Malcolm, Andrew Pawley and Meredith Osmond. 2003. The Lexicon of Proto Oceanic. The Culture and Environment of Ancestral Oceanic Society, vol. 2: The Physical Environment. Canberra: Pacific Linguistics.

Rumsey, Alan. 2008. Confession, anger, and cross-cultural articulation in Papua New Guinea. Anthropological Quarterly 81:455-72.

—. 2009. War and peace in Highland PNG. Canberra: SSGM Discussion Paper Series 2009/7. Online: ips.cap.anu.edu.au/sites/ default/files/09_07_rumsey.pdf.

Strathern, Andrew. 1970. The female and male spirit cults in Mount Hagen. Man (n.s.) 5: 571-85.

Strathern, Marilyn. 1988. The Gender of the Gift. Berkeley: University of California Press.

Tuomela, Raimo. 2003. The we-mode and the I-mode. In Socializing Metaphysics - The Nature of Social Reality, ed. Frederick Schmitt, pp. 93-127. Lanham, MD: Rowman \& Littlefield.

Williams, Raymond. 1976. Keywords: A Vocabulary of Culture and Society. London: Croom Helm. 
This text is taken from New Mana: Transformations of a Classic Concept in Pacific Languages and Cultures, edited by Matt Tomlinson and Ty P. Kāwika Tengan, published 2016 by ANU Press, The Australian National University, Canberra, Australia. 